УДК 349.6

DOI https://doi.org/10.32849/2663-5313/2020.4.20

Христина Чопко, канд. юрид. наук, асистент кафедри сочіального права

Львівського начіонального університету імені Івана Франка

\title{
ПРАВОВІ ЗАСАДИ ФОРМУВАННЯ ПРИРОДНО-ЗАПОВІДНОГО ФОНДУ УКРАЇНИ
}

Стаття присвячена аналізу правових засад формування природно-заповідного фонду України і охорони його територій і об'єктів. Шляхом дослідження наукової літератури було з'ясовано, що формування територій і об'єктів природно-заповідного фонду розпочалося ще за доби звичаєво20 права, а їх охорона була самостійним предметом дослідження в праві. До природно-заповідного фонду України належать природні території та об'єкти, а саме природні заповідники, біосферні заповідники, начіональні природні парки, регіональні ландшафтні парки, заказники; пам'ятки природи; заповідні урочища та штучно створені об'єкти: ботанічні сади, дендрологічні парки, зоологічні парки, парки-пам'ятки садово-паркового мистеитва. Важливим елементом правової охорони територій та об'єктів природно-заповідного фонду України є державне й локальне управління у сфері організаиій, ефективного використання природно-заповідного фонду України, відтворення його природних комплексів й об'єктів. Це дає можливість оцінити стан дотримання екологічних вимог за використання територій та об'єктів природно-заповідного фонду України, вжити необхідних заходів у разі порушення режиму їх використання й застосувати заходи юридичної відповідальності до порушників. Запобіганню втрати частини гено-, демо- й екофонду країни, забезпеченню збалансованого, ощадливого та невиснажливого використання природних ресурсів на значній частині території України, розвитку ресурсної бази для заняття туризмом, відпочинку й оздоровлення населення, зростанню природно-ресурсного потениіалу на суміжних з національною екологічною мережею землях сільськогосподарського призначення, удосконаленню природоохоронної нормативно-правової бази та ї̈ гармонізачії з міжнародною базою тощо сприяє утворення начіональної екологічної мережі України. Метою формування екологічної мережі є збереження й відтворення біологічного різноманіття, забезпечення екологічної рівноваги на території України, створення природних умов для життя й розвитку людини в екологічно збалансованому природному середовищі, максимально наближеному до природних умов.

Ключові слова: природно-заповідний фонд, території природно-заповідного фонду, об'єкти природно-заповідного фонду, екологічна мережа, структура екологічної мережі.

Постановка проблеми. Формування правових засад використання й охорони територій та об'єктів природно-заповідного фонду є надзвичайно актуальним питанням ще $з$ доби звичаєвого права. Оскільки підтримці екологічної рівноваги й забезпеченню екологічної безпеки поряд зі збалансованим i невиснажливим природокористуванням сприяють території та об'єкти, які мають особливу природоохоронну, наукову, естетичну, рекреаційну та іншу цінність, виключені 3 активного господарського використання, і щодо них встановлено особливий режим використання й охорони.

У зв'язку з особливою цінністю й важливістю територій та об'єктів природно-заповідного фонду України він охороняється як національне багатство, щодо нього встановлено особливий режим використання й охорони. Україна розглядає природнозаповідний фонд як складову частину світо- вої системи природних територій та об’єктів і необхідну умову забезпечення біологічного й ландшафтного різноманіття, а на території природно-заповідного фонду України обмежується або повністю забороняється людська діяльність.

Питання формування й охорони територій та об'єктів природно-заповідного фонду на монографічному рівні не досліджувалися. Проблематику формування й функціонування природно-заповідного фонду розглядали у своїх роботах Г.І. Балюк, I.I. Каракаш, О.М. Ковтун, М.В. Краснова, В.Л. Мунтян, Н.I. Титова, А.І. Черемнова та інші.

Метою статті $€$ дослідження поняття «природно-заповідний фонд», виявлення сутнісних ознак досліджуваного поняття, а також пропозиції щодо розв'язання проблем формування й функціонування природно-заповідного фонду України. 
Виклад основного матеріалу. Ще на початку XIV ст. виділялись території для охорони вимираючих турів. У часи правління Петра I заповідниками були оголошені корабельні ліси, а також ліси навколо великих міст і вздовж річок та інших водойм [1, с. 116]. У 1889 р. власник маєтку АсканіяНова виділяе ділянку українського степу, повністю вилучивши ऑï з господарського використання. У перші десятиліття XX ст. був створений заповідник на території маєтку Пилявин на Волині, де охоронялися зубри, олені, бобри та інші мисливські види тварин [2, с. 87-88].

Національно-визвольні змагання українського народу характеризуються суперечливим процесом формування правових засад охорони територій та об'єктів природно-заповідного фонду України. Так, Центральна рада у 4-му Універсалі проголосила Українську Народну Республіку власником природних багатств, у тому числі заповідних територій. Щоправда, це положення мало швидше політичний характер, оскільки жодних заходів з охорони заповідних територій не вживалося. Уже перша світова війна завдала значної шкоди заповідним територіям, деякі з них були знищені.

Період 1919-1927 рр. характеризується значним розвитком заповідної справи. Почали вживатися заходи щодо охорони курортів Кримського півострова, Одеси, Голої Пристані, Бердянська; були створені нові заповідні об'єкти, зокрема в Криму для охорони тваринного світу був створений Кримський заповідник; був прийнятий Декрет «Про заповідник «Чаплі» (АсканіяНова), який згодом перейменують на Державний степовий заповідник.

У 1921 р. засновано державний заповідник плавнів «Конча-Заспа» в районі Києва, a 1923 р. - Державний лісостеповий заповідник імені Т.Г. Шевченка в районі м. Канева на правому березі Дніпра. Зроблені спроби створення органів і структур державного управління природно-заповідними територіями та об'єктами, першою такою установою була секція (з 1924 р. - комісія) охорони природи Сільськогосподарського наукового комітету Наркомзему, згодом - Комітет по заповідниках.

Індустріалізація, суцільна колективізація, масові репресії та голод спричинили значне сповільнення розвитку заповідної справи. Ліквідуються природоохоронні органи, функції охорони природи передаються господарським відомствам, заповідні території включаються в цивільний обіг, сповільнюється процес заповідання. У 1940-1950 рр. відбувається відродження заповідної справи, яке було перервано війною. Зокрема створюється Управління по заповідниках, зоопарках і зоосадах. Водночас прийнята 29 серпня 1951 р. Постанова Ради Міністрів СРСР «Про заповідники» стала початком занепаду заповідної справи, адже скорочується кількість територій, на які поширювався природно-заповідний режим, значна їх кількість стає предметом цивільно-правових угод [3, с. 9]. Від 1968 р. спостерігається стабілізація й розвиток заповідної справи: розроблено класифікацію територій та об'єктів природно-заповідного фонду, яка діє й сьогодні (з деякими змінами й доповненнями). Постанова ЦК КПУ та Ради Міністрів УРСР від 18 листопада 1988 р. проголосила заповідну справу пріоритетним напрямом державної природоохоронної діяльності. Природоохоронні норми поступово перестають бути складовою цивільного законодавства, формується система природно-заповідного законодавства [3, с. 10]

Доба незалежності України характеризується збільшенням територій та об'єктів природно-заповідного фонду, біологічним і ландшафтним різноманіттям. Необхідність виділення територій та об'єктів зі спеціальним режимом охорони й відтворення обумовлена положенням Конституції України. Згідно зі ст. 50 Основного Закону кожному гарантується право на безпечне для життя та здоров’я довкілля [4].

Природно-заповідний фонд України становлять ділянки суші й водного простору, природні комплекси та об'єкти яких мають особливу природоохоронну, наукову, естетичну, рекреаційну та іншу цінність і виділені в цілях збереження природного різноманіття ландшафтів, генофонду тваринного й рослинного світу, підтримання загального екологічного балансу й забезпечення фонового моніторингу навколишнього природного середовища [5; 6].

Площа природно-заповідного фонду України становить понад 2,715 млн га, тобто майже 4,5\% території нашої держави. Під особливою охороною перебувають майже 7040 територій та об’єктів [7]. До природно-заповідного фонду належать природні території та об'єкти - природні заповідники, біосферні заповідники, національні природні парки, регіональні ландшафтні парки, заказники (ландшафтні, лісові, ботанічні, загальнозоологічні, орнітологічні, етимологічні, іхтіологічні, гідрологічні, загальногеологічні, палеонтологічні, карстово-спелеологічні); пам'ятки природи (комплексні, ботанічні, зоологічні, гідрологічні); заповідні урочища та штучно створені об'єкти: ботанічні сади, дендрологічні й зоологічні парки, парки пам'ятки садово-паркового мистецтва. 
Різноманітність складових елементів системи особливо охоронюваних об'єктів і територій викликає певні труднощі. Так, законодавець не визначив, які саме категоpiї природно-заповідного фонду України належать до територій, а які - до об'єктів. O.M. Ковтун вважає, що об'єктом природно-заповідного фонду необхідно вважати пам'ятки природи, що є невеликими за площею унікальними природними утвореннями або такими, що практично не потребують окремої території (дерева, скелі, джерела, печери тощо). Решта категорій природнозаповідного фонду, на переконання науковця, мають позначатися терміном «територія» $[3$, с. 88$]$.

Оптимізація мережі територій та об'єктів природно-заповідного фонду, а також подальший розвиток заповідної справи в Україні повинні бути забезпечені шляхом збільшення площі територій та об'єктів природно-заповідного фонду, оскільки відсоток заповідності $€$ важливим екологічним показником. Пріоритетний розвиток повинні мати групи об’єктів високої категорії заповідності, в першу чергу багатофункціональних (національних природних парків, біосферних і природних заповідників), створення їх у регіонах, недостатньо представлених у природно-заповідному фонді, оптимізація кордонів наявних об'єктів природно-заповідного фонду з метою покращення умов для збереження природно-заповідних комплексів.

Важливим елементом правової охорони територій та об'єктів природно-заповідного фонду є діяльність органів державного управління у сфері організації, ефективного використання природно-заповідного фонду України, відтворення його природних комплексів та об'єктів [3, с. 9].

Можливість оцінити стан дотримання екологічних вимог, вживати необхідних заходів у разі порушення режиму використання територій та об'єктів природно-заповідного фонду й застосувати заходи юридичної відповідальності до порушників дає саме державне управління природно-заповідним фондом.

Локальне управління природно-заповідним фондом здійснюють адміністрації заповідних територій та об'єктів. Відповідно до ст. 12 Закону України «Про природнозаповідний фонд України» управління природними заповідниками, біосферними заповідниками, національними природними парками, регіональними ландшафтними парками, а також ботанічними садами, дендрологічними парками й зоологічними парками загальнодержавного значення здійснюють спеціальні адміністрації [6]. Спеціальні адміністрації можуть створюватися також для управління ботанічними садами, дендрологічними парками, зоологічними парками місцевого значення й парками - пам'ятками садово-паркового мистецтва за рішенням органів, у віданні яких вони перебувають. До запропонованого поділу є зауваження, зокрема незрозуміло, до якої 3 названих категорій належать пам'ятки природи, що займають великі площі та є унікальними за своєю природою утвореннями, тобто мають особливу природоохоронну, наукову, естетичну чи іншу цінність лише в сукупності з відповідною територією. Тому такий поділ, як видається, не може слугувати критерієм розмежування територій від об'єктів природно-заповідного фонду.

Однією з головних проблем формування природно-заповідного фонду $€$ роздержавлення й приватизація земель, яка відбувається без адекватного системного законодавчого забезпечення цього процесу й не дає реальної можливості впливати на формування природно-заповідного фонду надалі. Потребує вдосконалення регламентований Законом України «Про природно-заповідний фонд України» порядок зміни меж і позбавлення статусу заповідних комплексів. Зміна меж чи скасування статусу територій та об'єктів природно-заповідного фонду здійснюється відповідно до передбаченого законодавством порядку створення й оголошення територій та об'єктів природно-заповідного фонду, тобто за клопотанням обласних, Київської й Севастопольської міських державних адміністрацій, наукових установ, природоохоронних громадських об'єднань або інших зацікавлених підприємств, установ, організацій і громадян (ст. 51 Закону України «Про природно-заповідний фонд України») [6].

Не передбачено, які саме відомості повинно містити таке клопотання, адже закріплений в Законі перелік відомостей стосується обгрунтування створення чи оголошення території або об'єкту природно-заповідного фонду.

Як справедливо наголошує О.М. Товкун, чинний спрощений порядок зміни меж чи позбавлення об'єктів і територій статусу природно-заповідного фонду обумовлює неконтрольований процес роздержавлення й приватизації земель природно-заповідного фонду [8, с. 204].

Зміна пріоритетів правової охорони природи, тобто поступовий перехід від охорони конкретних територій та об'єктів природнозаповідного фонду до охорони й збереження біорізноманіття відбувається шляхом формування екологічної мережі України як складової Всеєвропейської екологічної мережі [3, с. 89]. Відповідно до рекомендацій 
Всеєвропейської стратегії збереження біологічного та ландшафтного різноманіття (1995р.) формується Всеєвропейська екологічна мережа як єдина просторова система територій країн Свропи з природним або частково зміненим станом ландшафтів. Свропейська екомережа включає: природні ядра (осередки) для збереження екосистем, середовищ існування, видів і ландшафтів європейського значення; екокоридори або перехідні зони для забезпечення взаємозв'язків між природними екосистемами - елементи дефрагментації природних масивів і міграційні шляхи водночас; відновлювальні райони, де $\epsilon$ потреба у відновленні порушених елементів екосистем, середовищ існування й ландшафтів, або повне відновлення деяких районів; буферні зони, які сприяють зміцненню мережі та ï захисту від впливу негативних зовнішніх чинників.

На виконання цих рекомендацій Україною (єдиною зі всіх країн СНД) була розроблена Загальнодержавна програма формування національної екологічної мережі України на 2000-2015 рр. У цьому документі вперше було закріплено законодавче визначення терміну «екологічна мережа» як єдиної територіальної системи, що охоплює ділянки природних ландшафтів, які підлягають особливій охороні, а також території та об'єкти природно-заповідного фонду, курорти й лікувально-оздоровчі, рекреаційні, водозахисні, полезахисні території та об'єкти інших типів, що визначаються законодавством України та $є$ частиною структурних територіальних елементів екологічної мережі - природних регіонів, природних коридорів і буферних зон $[9$, с. 20$]$.

3 метою реалізації Загальнодержавної програми формування національної мережі України на 2000-2015 рр. ухвалено спеціальний Закон «Про екологічну мережу України» [10]. Тут екологічна мережа України (екомережа) визначається як єдина територіальна система, яка утворюється з метою поліпшення умов для формування й відновлення довкілля, підвищення природно-ресурсного потенціалу території України, збереження ландшафтного й біорізноманіття, місць оселення й зростання цінних видів тваринного й рослинного світу, генетичного фонду, шляхів міграції тварин через об'єднання територій та об'єктів природно-заповідного фонду, а також інших територій, які мають особливу цінність для охорони навколишнього природного середовища й відповідно до законів і міжнародних зобов'язань України підлягають особливій охороні.

Структуру екомережі, крім територій та об’єктів природно-заповідного фонду, земель оздоровчого й рекреаційного призначення, водозахисних і полезахисних територій, формують також землі водного й лісового фондів; земельні ділянки, в межах яких є природні об’єкти, що мають особливу природну цінність; земельні ділянки, на яких зростають природні рослинні угруповання, занесені до Зеленої книги; території, які є місцем перебування чи зростання видів тваринного й рослинного світу, занесених до Червоної книги України; частково землі сільськогосподарського призначення; радіоактивно забруднені землі, що не використовуються й підлягають окремій охороні як природні регіони з окремим статусом, і деякі інші території та об’єкти. Отже, формування екологічної мережі поряд 3 територіями та об'єктами природно-заповідного фонду охоплює низку інших елементів, що мають особливу природну цінність і є зовсім новим та перспективним напрямом природоохоронної діяльності України.

\section{Висновки}

Формування й функціонування природнозаповідного фонду, а також подальший розвиток заповідної справи в Україні повинні бути забезпечені шляхом збільшення площі територій і об'єктів природно-заповідного фонду, оскільки відсоток заповідності є важливим екологічним показником збереження територій та об'єктів, які мають особливу природоохоронну, наукову, естетичну, рекреаційну та іншу цінність. Саме тому група об'єктів i територій природно-заповідного фонду набуває статусу заповідності, кордони таких об'єктів і територій оптимізуються як гарантія покращення умов для збереження біологічного й ландшафтного різноманіття.

\section{Список використаних джерел:}

1. Степанов $€$. Історико-правові етапи становлення і розвитку екологічної функції держави в Україні. Юридична Україна. 2010. № 11. C. $112-117$.

2. Черемнова А.И. Создание и охрана территорий и объектов природно-заповедного фонда Украины. Природоресурсное, аграрное, экологическое право: теория, практика, тенденции развития : материаль Междунар. науч.-практ. конф.. Ижевск, 2008. С. 87-93.

3. Ковтун О.М. Правові аспекти охорони територій та об'єктів природно-заповідного фонду України : автореф. ... дис. канд. юрид. наук : 12.00.06. Київ, 2008. 16 с

4. Конституція України : Закон України від 28 червня 1996 р. № 254к-ВР / Верховна Рада України. Відомості Верховної Ради Украӥни. 1996. № 30. Ст. 141.

5. Про охорону навколишнього природного середовища : Закон України від 25 червня 1991 р. / 
Відомості Верховної Ради України. Відомості Верховної Ради України. 1991. № 41. Ст. 540.

6. Про природно-заповідний фонд України : Закон України від 16 червня 1992 р. / Вiдомості Верховної Ради України. Відомості Верховної Ради України. 1992. № 34. Ст. 502.

7. Національна доповідь України про гармонізацію життедіяльності суспільства у навколишньому природному середовищі. Спеиіальне видання до 5-ї Всеєвропейської конферениіӥ міністрів навколишнього середовища «Довкілля для Європи». Київ, 2003. 108 с.
8. Товкун О.М. Особливості правового режиму біосферних заповідників як складника екологічної мережі. Респ. міжвідом. наук. зб. Харків, 2008. Вип. 95. С. 200-204.

9. Парчук Г.В. Мотиви та принципи створення європейської екомережі : матеріали Всеукр. загальнотеор. та наук.-практ. конф., Канів, 11-14 жовтня 1994 р. Канів, 1999. С. 20-25.

10. Про екологічну мережу України : Закон України від 24 вересня 2004 р. № 1864-IV / Відомості Верховної Ради України. Відомості Верховної Ради України. 2004. № 45. Ст. 502.

The article is dedicated to the analysis of the legal principles of forming the Nature Reserve Fund of Ukraine and conserving its territories and objects. Basing upon the study of the academic literature the following conclusion has been drawn. The formation of the territories and objects belonging to the nature reserve fund dates back as far as the period of the customary law with their conservation being a separate object of research in the field of law. The Nature reserve fund of Ukraine includes the natural areas and objects, namely the wildlife reserves, the biosphere reserves, the national nature parks, the regional landscape parks, wildlife sanctuaries; natural monuments; reserved natural boundaries; and artificial natural objects; botanic gardens; dendrological parks; zoological parks; garden design monumental parks. One of the most crucial elements of the legal protection of the territories and objects belonging to the Nature reserve fund of Ukraine is the state and local administration in the sphere of organization and the efficient use of the Nature reserve fund of Ukraine, the recreation of its natural habitats and objects. Thus it enables us to evaluate the state of fulfilling the ecological requirements when exploiting the territory and objects of the Nature reserve fund of Ukraine, take the necessary actions in case of violation of the land-use regime and apply legal liability measures against the offenders. The creation of the National ecological network of Ukraine contributes to the preventing the part of the genealogical, demographic and the ecological fund of the country; ensuring balanced, economical and reasonable use of natural resources in the considerable part of the Ukrainian territory; developing the resource base for tourism, recreation and rehabilitation of the population; the growth of the natural resourcepotential on the adjoining to the agricultural lands belonging to the national ecological network; improving the legal framework of the natural resource conservation and its harmonization with the international legal framework, etc. The aim of forming the ecological network is the preservation and recreation of the biological variety, ensuring the ecological balance on the territory of Ukraine, creating the natural conditions for life and development of a human being in an ecologically balanced environment as close to the natural conditions as possible.

Key words: nature reserve fund, territory of the nature reserve fund, object of the nature reserve fund, ecological network, ecological network structure. 